\title{
Rain Forests in Subtropical Mountains of Dominican Republic
}

\author{
Eusebio Cano', Alverto Veloz ${ }^{2}$, Ana Cano-Ortiz ${ }^{3}$ \\ ${ }^{1}$ Department of Animal Biology, Plant Biology and Ecology, (Botany), University of Jaen, Jaen, Spain \\ ${ }^{2}$ Botanical National Garden Rafael Ma, Moscoso of Santo Domingo, Dominican Republic \\ ${ }^{3}$ Department of Sustainability Interra, Resources and Engineering SL, Plaza of Spain, Salamanca, Spain \\ Email: ecano@ujaen.es, albertovelozramirez@yahoo.com, ana@interra.es
}

Received 20 March 2014; revised 19 April 2014; accepted 28 April 2014

Copyright (C) 2014 by authors and Scientific Research Publishing Inc.

This work is licensed under the Creative Commons Attribution International License (CC BY).

http://creativecommons.org/licenses/by/4.0/

c) (i) Open Access

\begin{abstract}
This article presents a study of the cloud forest dominated by the Prestoea montana (R. Graham) Nichols. This is a hyperhumid forest located in ravines and shaded areas with cloud condensation, and at heights ranging from 350 - 1250 masl. This type of forest is always found in thermal and mesotropical belts, without ever reaching the supratropical belt. This study was based on works published by other authors and on our own field sampling. The article begins by describing the geological, bioclimatic, biogeographic and floristic aspects of the areas in the study, specifically the hyperhumid areas in the central and eastern mountains. Due to the scarcity of phytosociological works on this area, we apply a statistical treatment to compare our communities with other associations described in Cuba. This comparison reveals that these forest groups are floristically quite distant from each other, both with regard to alliance and association species. We therefore propose two new communities: Cyathea furfuracea Baker and Prestoea montana (Grah.) Nichol; Ormosia krugii Urb. and Prestoea montana (Grah.) Nichol.
\end{abstract}

\section{Keywords}

Cloud Forest, Hispaniola, Communitiy, Central and Eastern Ranges

\section{Introduction}

The island of Hispaniola has an area of 76,484 $\mathrm{km}^{2}$ and is located between parallels 17 - $19 \mathrm{~N}$; along with Cuba, Jamaica and Puerto Rico, it belongs to the group of the largest islands in the Caribbean region. The geological origin of the mountains on the island dates from the Cretaceous and Oligocene-Miocene periods, with the exception of the intra-mountain valleys formed by material deposits during the Quaternary period [1]. There is a 
predominance of calcareous materials of a karstic nature, marbles, limestones and materials from Quaternary deposits, a large central nucleus of siliceous materials and the presence of serpentines [2]-[4]. The island has a mountainous terrain with various mountain formations such as the eastern, central, and northern ranges and the mountains of Bahoruco and Niebla. The northwest-southeast orientation of the mountains and the prevailing direction of the Atlantic winds gives rise to a permanent cloud layer, and causes high rainfall on north-northeast-facing slopes. The island of Hispaniola has a thermotype which ranges from the infratropical to the supratropical, and an ombrotype which varies from semiarid to hyperhumidm [5]. From the biogeographical point of view, the Antillean archipelago, and specifically the island of Hispaniola, is part of the Mesoamerican-Caribbean region [6] and within the province of Hispaniola [2] [3], with a strong influence from the biogeographical province of the Lesser Antilles [7].

There are very few vegetation studies existing on Hispaniola, with the exception of a few works of a physiognomical nature published intermittently by the Dr. Rafael Moscoso National Botanical Garden. We should mention the works of [8]-[18]; and more recent work: [2] [3] [5] [19]. The plant communities in this study were included in our previous works in the humid-hyperhumid areas of the island, where there is a predominance of the forests of Ocotea, Magnolia, Weinmanio and Cyrilla. The species Prestoea montana (R. Graham) Nichols., known in the Caribbean region as "manacla", is distributed around the Lesser and Greater Antilles, with the exception of the Bahamas and the centre west of Cuba [20]. The objective of this work is to characterize the cloud forests of Dominican Republic, and examine the state of conservation, taking into consideration the number of endemic species present.

\section{Material and Methods}

A study was made of the communities dominated by Prestoea montana (R. Graham) Nichols. (Arecaceae) in the Dominican Republic. A series of vegetation studies were carried out in areas with high rainfall including the central and eastern mountain ranges, using sampling plots with an area of $500-2000 \mathrm{~m}^{2}$. Due to the lack of vegetation studies on Hispaniola, we analysed the works on the vegetation of Cuba by [21]-[25]. The criteria of [26] were applied for the dynamic-catenal landscape study. The various vegetation tables were used to create an Excel chart with 381 rows (species) $\times 8$ columns (these tables included 33 inventories). Statistical treatments were applied (cluster and ordination) to separate the communities described for Cuba from those of Hispaniola, and a table was drawn up in which the biotypes were separated: $\mathrm{A}=$ tree of $6-25 \mathrm{~m}, \mathrm{Ar}=$ shrub of up to $6 \mathrm{~m}, \mathrm{Tr}$ = climbing species (creepers), Ep = epiphytes, ArEp = epiphytic shrub, $\mathrm{H}=$ herbs (includes perennial and annual herbs). The statistical treatment was done on an adaptation of the 34 conversion, substituting the indices of abundance-dominance for synthetic indices to give the following equivalence: $\mathrm{I}=3$, II $=4$, III $=5$, IV = 6, V = 7 [27]. Once the indices had been converted, a cluster analyses was applied using the Jaccard distance, which marks the distance between the associations studied. For the bioclimatic study we followed the criteria established in [28] and on the web page www.globalbioclimatics.org; and in the biogeographical treatment we took into consideration prior studies by [2] [3] [6] [7] [29].

\section{Results and Discussion}

We [2] have recently included the (cloud forest) vegetation of the humid and hyperhumid areas of Hispaniola in the forests of Occotea, Magnolia, Weinmannia and Cyrilla. According to 1, the first class is distributed throughout the rainy mountains of the Caribbean, and particularly in the mountains of eastern Mexico and the Antilles. This author characterises the communities of Ocotea and Magnolia by the constant presence of tree ferns and the abundance of epiphytes and mosses. He also recognises the presence of the forest of Weinmannia and Cyrilla in the high mountains of the Caribbean region, which is rich in epiphytic orchids and tree ferns. Both classes are mentioned by the authors [30] and [31], who include the cloud forests of the heights of the Antilles in Weinmannio-Cyrilletea, without clearly specifying the differences between both classes.

In our opinion there does not appear to be a high degree of floristic, synecological and biogeographical difference between these two groups of forests, as the cloud forest is included in both of them. The only differences we can observe is the presence of a hyperhumid ombrotype with a high number of epiphytes from the Orchidaceae family for the forests of Weinmannia and Cyrilla, and a decrease in species from the genera Ocotea, Persea and Magnolia; this class tends to occupy the shady and hyperhumid ravines of the Caribbean, whereas the Oc- 
cotea and Magnolia grows in environments with humid ombrotypes and is less rich in epiphytic species.

The high number of tree ferns and epiphytes in the Prestoea montana communities allows us to include them in the group of Weinmannia and Cyrilla. In the statistical analyses carried out, the application of a cluster using the Jaccard distance reveals that both the Prestoea montana communities (7 and 8) in Hispaniola are totally separate from the communities (1 and 2) Clethra cubensis A. Rich. and Pinus maestrensis Bisse; Hyeronima nipensis Urb. and Sloanea curatellifolia Griseb. given by [21] for the Sierra Maestra mountains in Cuba, and included in the forests of Ocotea and Magnola. They are also separate from the communities recently described for Cuba (3, 4, 5 and 6) in the cluster (Figure 1). [22] describes the community of (3) Alchornea latifolia Sw. and Calophyllum rivulare Bisse growing among metamorphic rocks with a ferralitic character; [32] describe the community of (4) Prunus myrtifolia (L.) Urb. and Guarea guidonea (L.) Sleumer in the Sierra Maestra (Cuba), and mention the evergreen tropical rainforests which grow on soils rich in andesites; and [23] [24] give the communities (5) Ocotea coriacea (Sw.) Britt. and Phoebe elongata (Vahl) Nees on the lower parts of the "mogotes" on the Gran Meseta of Guantánamo and (6) Guarea guidonea and Zanthoxylum martinicense (Lam.) DC. which grow on tufas and limestone materials. The four communities described (3 to 6) have been included by their authors in the forests of Swietenia mahagoni (L.) Jcaq. and Calophyllum calaba L. The communities of Prestoea montana that we propose for Hispaniola present a Jaccard distance of over $90 \%$ difference from the associations described for Cuba. The statistical cluster analysis is corroborated by means of a DECORANA ordination analysis. This analysis separates two groups (Figure 2): the communities of Prestoea montana (D1) and a group of communities described by [22] [24] with the exception of the community (3) Alchornea latifolia and Calophyllum rivulare which presents strong floristical differences with communities 4, 5 and 6 in group (D2). Finally in this ordination analysis, the communities described by [4] are highly separated, and they also present a floristical composition which is distant from the rest, due to the presence of 15 tree species which are exclusive to the community Clethra cubensis and Pinus maestrensis, and 21 to Hyeronima nipensis and Sloanea curatellifolia, which can be modified by climate change [32].

The ravines and hyperhumid areas of the central range are home to a community of Prestoea montana (D1), characterised by the tree species Cyathea furfuracea Baker, Alsophila minor (D.C. Eaton) R.M. Tryon, Byrsonima lucida (Mill.) L.C. Rich, Guatteria blainii (Griseb.) Urb., Exostema elliptica Griseb., and the endemic trees Rondeletia ochracea Urb., Malpighia macracantha Ekm. \& Nied., and Didymopanax tremulus Krug. \& Urb. This new community has $23.07 \%$ tree (A) species, $16.66 \%$ creepers (Tr) and $21.79 \%$ epiphytes (Ep) - with a marked presence of the endemic element Pleurothalis domingensis Cogn.-representing $61.53 \%$ of forest elements, as opposed to $38.47 \%$ of shrubs (Ar) and herbs (H) derived from forest degradation [33]. This fact, together with the dense cover presented by $100 \%$ of the sampling plots, indicates that these forests are in a good state of conservation [34]. This "manacla" community grows on siliceous substrates in north-facing ravines in the central mountain range, in hyperhumid environments in the thermal and mesotropical belts. We thus propose the new community de Cyathea furfuracea Baker and Prestoea Montana which occupies the biogeographical area (A16) of the central mountain range (Photo 1). This association contacts catenally with an endemic forest of Magnolia pallescens Urb. \& Ekm. (Figure 3).

The eastern range has a rainfall of over $2000 \mathrm{~mm}$, as it is increased by the almost permanent cloud cover at night, and can reach a yearly average of $2500 \mathrm{~mm}$. Thus the ombrotype in the ravines is hyperhumid. There are two types of substrate: siliceous material from magmatic (volcanic) rocks in the central-southern part; and karstic material in the more northern areas which form the complex known as "mogotes". These are steeply sloping calcareous mounds -sometimes even with vertical sides which enclose small V-shaped or U-shaped valleys, and are areas with an abundance of epiphytic plants due to the high rainfall [18]. These areas comprising numerous small mounds constitute the Los Haitises National Park in which we have found 45 endemic species, although [10] describe 92 species, of which 14 are exclusive to this biogeographic area A6, compared to the 9 species we found in area A5. Although the eastern mountain range contains areas which have undergone widespread alteration [16], there are still territories with a good state of conservation. Shade-loving forest predominates, and in the valleys is characterised by Prestoea montana, Cyathea arborea (L.) J. E. Smith, Sloanea berteriana Choisy, Ormosia krugii Urb., Bactris plumeriana Mart., and Guarea guidonea; this "manacla" plantation grows in enclosed valleys and on slopes which are completely covered with litterfall; further up the mounds or "mogotes" as the humidity decreases the "manacla" plantation is enriched by Didymopanax morotononi (Aubl.) Decne \& Planch and Oreopanax capitatus (Jacq.) Decne \& Planch; in this situation there is a decrease in epiphytes, and 

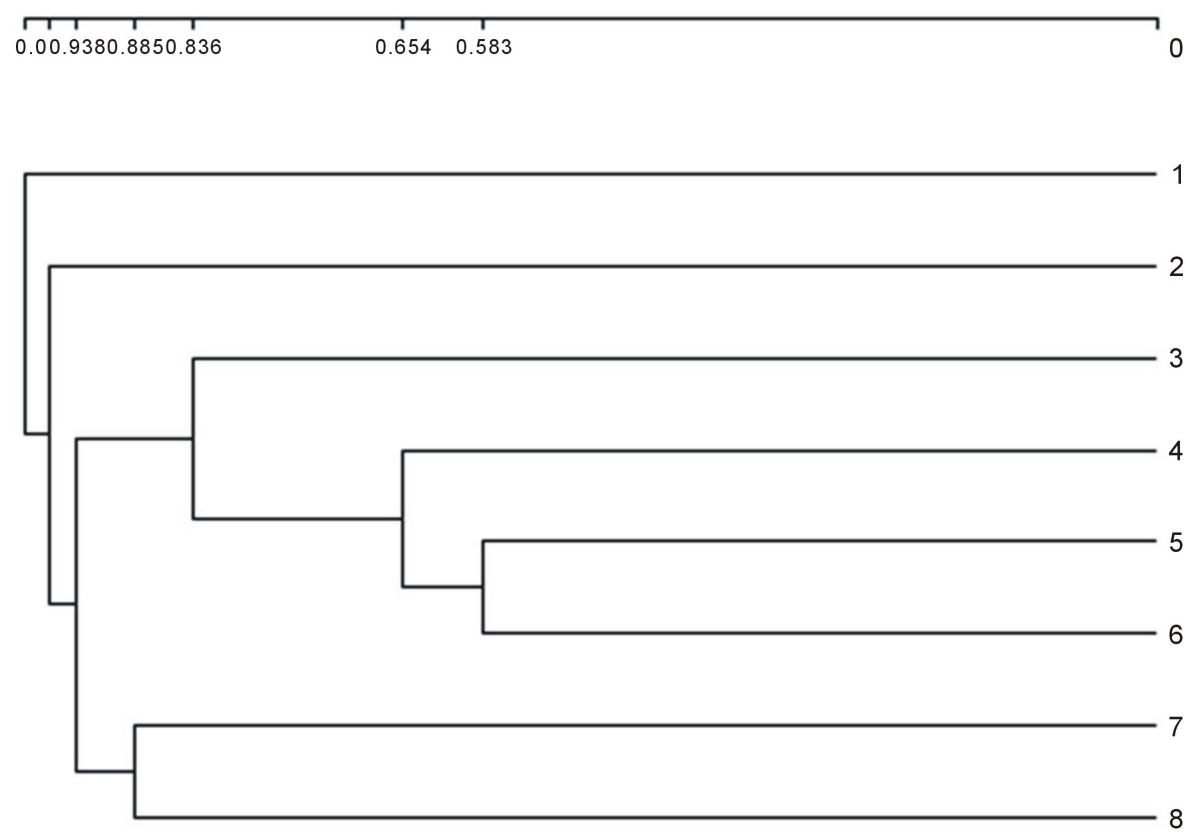

Figure 1. Cluster based on 8 phytosociological tables using Jaccard distance.

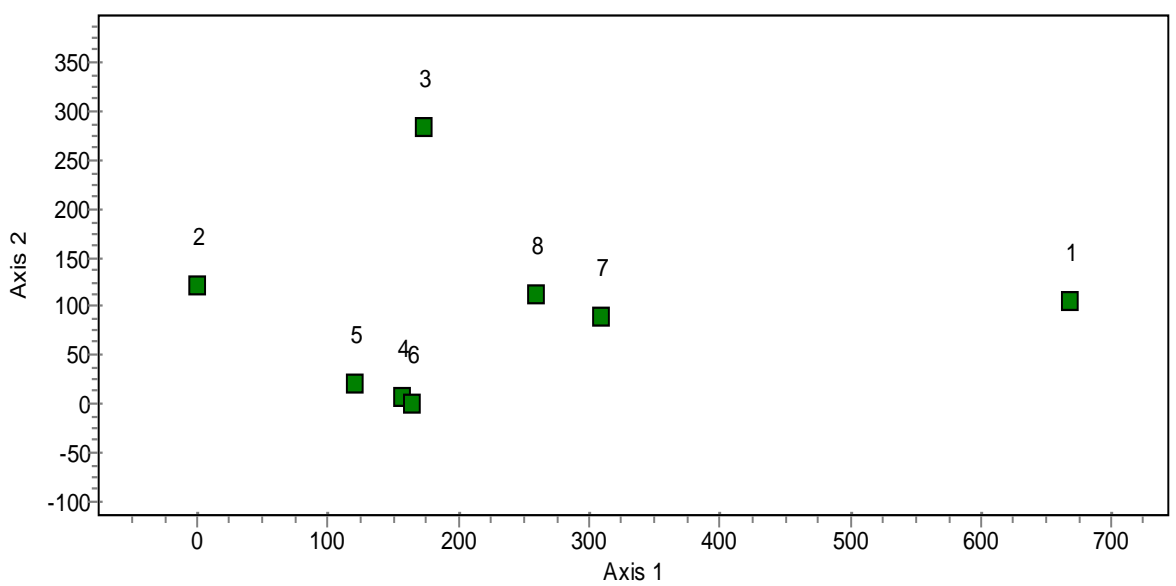

Figure 2. DECORANA ordination analysis. Forests of Prestoea montana in the Dominican Republic (D1). The rest of the associations have been described in Cuba.

thus within the new community of Ormosia krugii Urb. and Prestoea montana, there is a dry variant (Photo 2). This variant coincides with the community of Sloanea berteriana and Ormosia kurgii proposed by [11] (Figure 4). When the "mogote" has vertical walls, the xericity is further accentuated with the appearance of xerophytic species such as Coccothrinax gracilis Burret, Coccothrinax argentea (Lodd.) Sarg., Bursera simaruba (L.) Sarg., Agave antillarum Descourt. [35]. This edaphoxerophilous community of Coccothrinax gracilis is very similar to the community we have described in the neighbouring biogeographical area of the Samaná peninsula, Coccothrinax gracilis burret and Bursera simarubae (L.) sarg. [36], but it differs due to the absence of species from the Cactaceae family.

\section{Conclusion}

The floristic and biogeographical differences between the cloud forest in Cuba and that of Hispaniola allow us to propose new forests which include the communities described above [21]. It includes forests of Cuba in a particular group, characterized by species: Myrsine microphylla Hayata, Ditta maestrensis Borhidi, Leoseneriella 


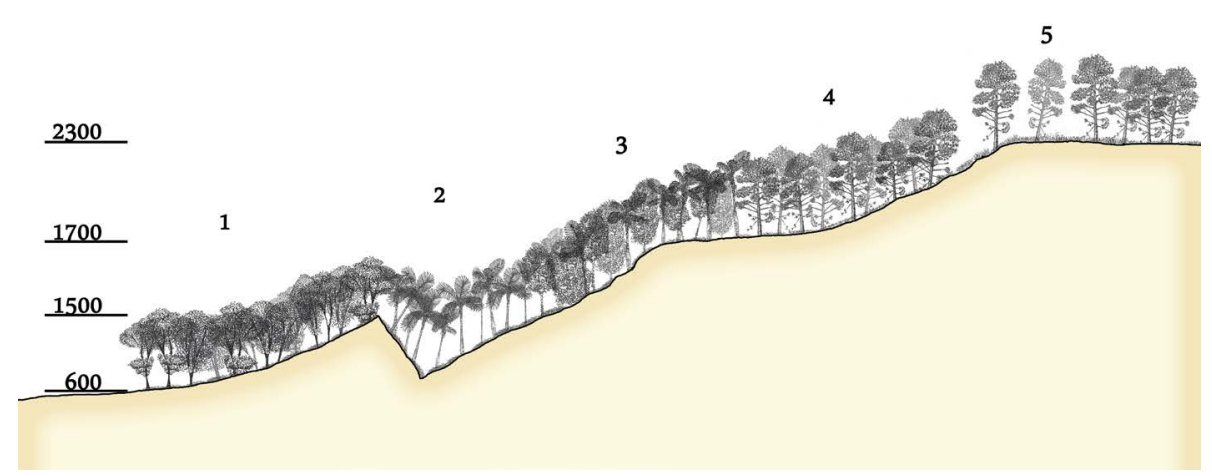

Figure 3. Profile of the vegetation of the central range. 1-Subhumid latifoliate forest. 2"Manacla" plantation of Cyathea furfuracea and Prestoea montana. 3-Community of Palo de Viento Didymopanax and Magnolia pallescens with isolated elements of Prestoea montana. 4-Pine forest of Pinus occidentalis belonging to the community of Dendropemon phycnophyllus Krug an urb. and Pinus occidentalis Sw. 5-Hemicryptophytic high-mountain grassland of Danthonia domingensis between the cleared pine forests of Pinus occidentalis. Profile altitude in meters (600 - 2300).

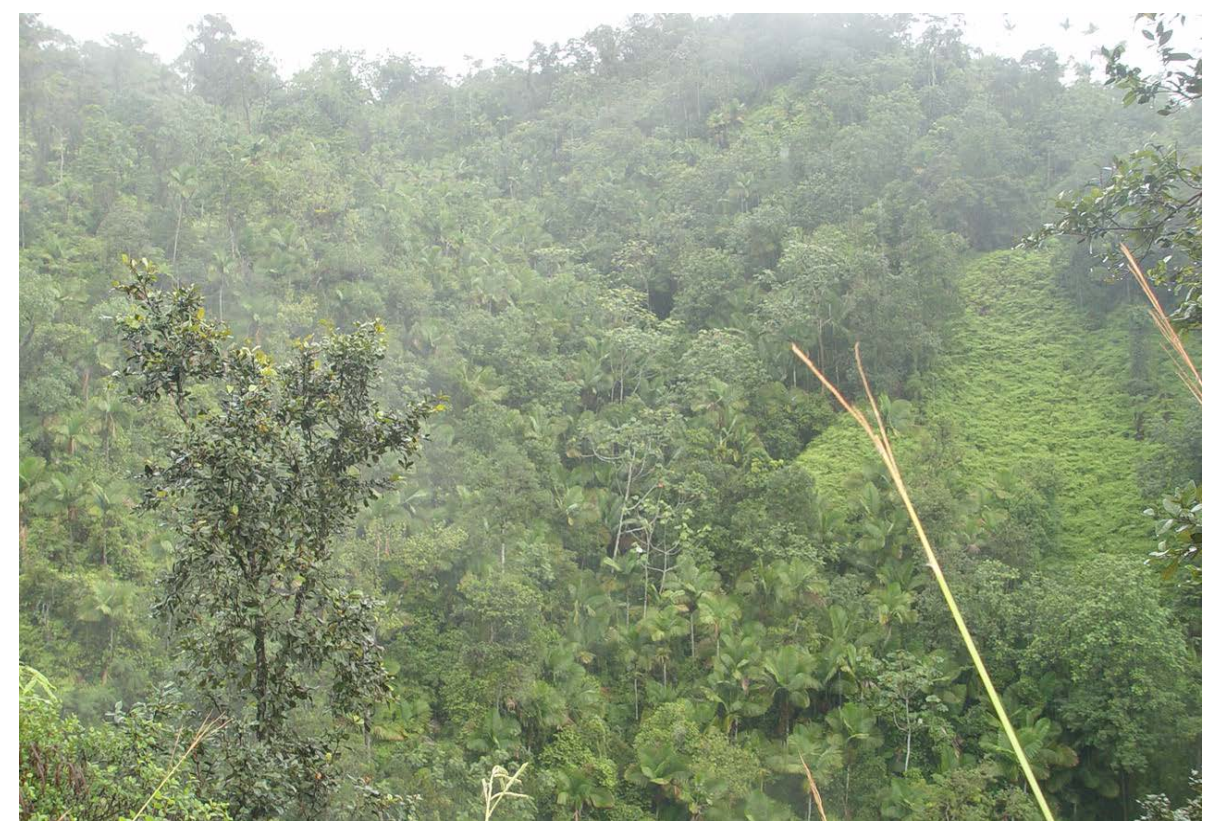

Photo 1. "Manacla" plantation in a ravine belonging to the community Cyathea furfuracea and Prestoea montana. Central range.

lenticellata C.Y. Wu, Garrya fadyenii Hook, and Hedyosmum nutans Sw.; along with the species endemic in Cuba: Tetrazygia elegans Urb., Scolosanthus maestrensis Alain, Nectandra reticularis Britton \& P. Wilson, Sapium maestrense Urb., Hedyosmum domingense Urb. var. cubense (Urb.) Todzia \& C.E. Wood, Henriettea ekmanii (Urb.) Alain, and Miconia turquinensis Urb. \& Ekman. In Hispaniola there is a group of plants with a widespread distribution throughout the island which grow on siliceous, neutral and carbonated substrates and act as characteristic species of the forests: Prestoea montana, Turpinia occidentalis (Sw.) G. Don, Clusia rosea Jacq., Miconia mirabilis (Aubl.) L.O. Williams, Ormosia krugii, Sloanea berteriana, Didymopanax tremulus, Didymopanax morototoni, Rondeletia ochracea Urb., Arthrostylidium multispicatum Pilger, and Mikania venosa A. Liogier. Highlights in the forests of the Spanish, two clearly defined subgroups, which are located on sili 


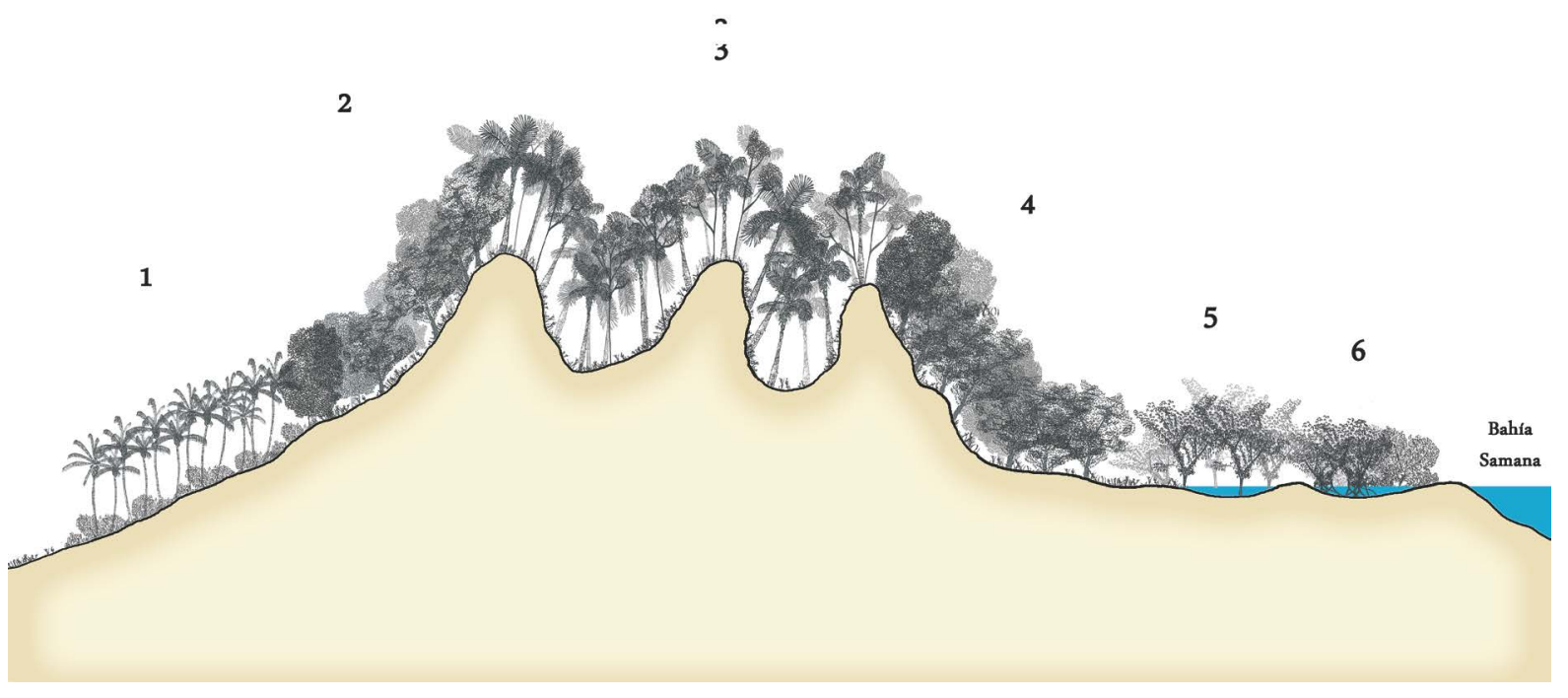

Figure 4. Profile of the vegetation of the Haitises (A6). 1-Coconut crops. 2-Latifoliate mahogany forest Swietenia mahagoni. 3-Ormosia krugii and Prestoea Montana which is enriched on the summits witt Didymopanax morotononi. 4 -Latifoliate mahogany forest of Swietenia mahagoni similar to 2. 5-Community Roystonea hispaniolana Bailey and Pterocarpus officinalis Jacq. 6-Community Machaerium lunatum (L.f.) Ducke and Rhyzophora mangle L.
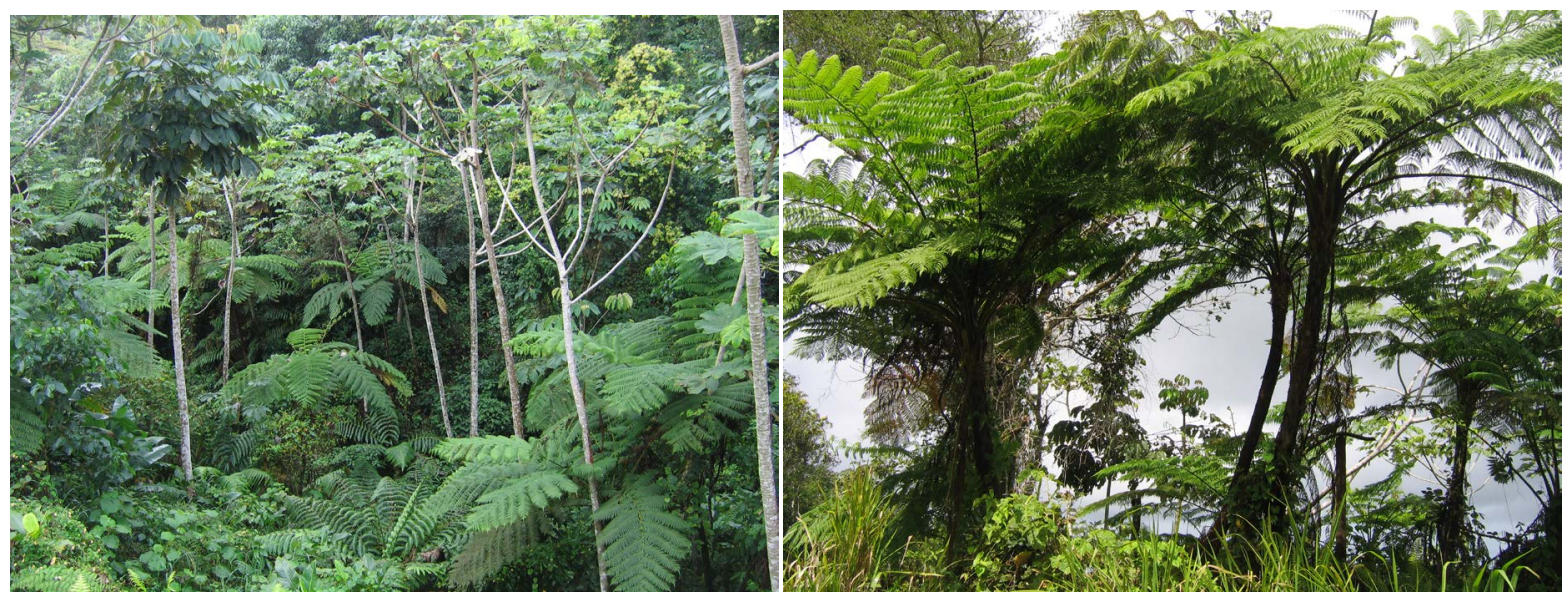

Photo 2. "Manacla" plantation rich in Cyathea arborea, belonging to the community Ormosia krugii and Prestoea montana. Eastern range.

ceous substrates Central mountain against those developed on basic substrates other mountains.

\section{References}

[1] Mollat, H., Wagner, B.M., Cepek, P. and Weiss, W. (2004) Geological Map of the Dominican Republic 1:250,000. Geolog. Jahrb., Hannover.

[2] Cano, E., Veloz Ramirez, A., Cano Ortiz, A. and Esteban Ruiz, F.J. (2009) Distribution of Central American Melastomataceae: Biogeographical Análisis of the Caribbean Islands. Acta Botanica Gallica, 156, 527-557. http://dx.doi.org/10.1080/12538078.2009.10516176

[3] Cano, E., Veloz Ramirez, A. and Cano Ortiz, A. (2010) Contribution to the Biogeography of the Hispaniola (Dominican Republic, Haiti). Acta Botanica Gallica, 157, 581-598. http://dx.doi.org/10.1080/12538078.2010.10516233

[4] Cano, E., Veloz Ramirez, A. and Cano Ortiz, A. (2011) Phytosociological Study of the Pinus occidentalis Forests in the Dominican Republic. Plant Biosystems, 145, 286-297. http://dx.doi.org/10.1080/11263504.2010.547685 
[5] Cano, E., Cano Ortiz, A., Del Río González, S., Alatorre Cobos, J. and Veloz, A. (2012) Bioclimatic Map of the Dominican Republic. Plant Sociology, 49, 81-90.

[6] Rivas-Martínez, S., Sánchez Mata, D. and Costa, M. (1999) North American Boreal and Western Temperate Forest Vegetation. Syntaxonomical Synopsis of the Potential Natural Plant Communities of North America, II. Itinera Geobotanica, 12, 5-326.

[7] Rivas-Martínez, S., Navarro, G., Penas, A. and Costa, M. (2011) Biogeographic Map of South America. A Preliminary Survey. International Journal of Geobotanical Reserarch, 1, 21-40. http://dx.doi.org/10.5616/ijgr110002

[8] García, R., Mejía, M. and Zanoni, T. (1994) Floristic Composition and Main Plant Associations in Evano Verde Scientific Reserve, Cordillera Central, Dominican Republic. Moscosoa, 8, 86-130.

[9] Guerrero, A., Jiménez, F., Höner, D. and Zanoni, T. (1997) The Flora and Vegetation of the Hill Barbecue, Cordillera Central, Dominican Republic. Moscosoa, 9, 84-116.

[10] Hager, J. and Zanoni, Th. (1993) The Natural Vegetation of the Dominican Republic: A New Classification. Moscosoa, 7, 39-81.

[11] Höner, D. and Jiménez, F. (1994) Vascular Flora and Vegetation of the Hill Horseshoe, Cordillera Oriental, Dominican Republic. Moscosoa, 8, 65-85.

[12] May, T. (1997) Early Stages of Succession in a Cloud Forest of Magnolia pallescens after Fire (Loma Casabito, Ebano Verde Scientific Reserve, Cordillera Central, Dominican Republic). Moscosoa, 9, 117-144.

[13] May, T. and Peguero, B. (2000) Flora and Vegetation of the Hill Mogote, Jarabacoa, Cordillera Central, Dominican Republic. Moscosoa, 11, 11-37.

[14] Mejía, M. and Jiménez, F. (1998) Flora and Vegetation of the Hill the Humeadora, Cordillera Central, Dominican Republic. Moscosoa, 10, 10-46.

[15] Mejía, M., García, R. and Jiménez, F. (2000) Sub-Region Fitogeográfica Barbecoa-Casabito: Floristic Richness and Its Importance in the Conservation of the Flora of the Spanish Island. Moscosoa, 11, 57-106.

[16] Slocum, M.G., Mitchell Aide, T., Zimmerman, J.K. and Navarro, L. (2004) Natural Regeneration of Subtropical Montane Forest after Clearing Fern Thickets in the Dominican Republic. Journal of Tropical Ecology, 20, 483-486. http://dx.doi.org/10.1017/S0266467404001646

[17] Zanoni, T. (1990) The Flora and Vegetation of Hill Diego de Ocampo, Cordillera Septentrional, Dominican Republic. Moscosoa, 6, 19-45.

[18] Zanoni, T., Mejía, M.M., Pimentel, J.D. and García, R.G. (1990) The Flora and Vegetation of the Haïtises, Dominican Republic. Moscosoa, 6, 46-97.

[19] Cano, E. and Veloz, A. (2012) Contribution to the Knowledge of the Plant Communities of the Caribbean-Cibensean Sector in the Dominican Republic. Acta Botanica Gallica, 159, 201-210. http://dx.doi.org/10.1080/12538078.2012.696933

[20] Lugo, A.E., Francis, J.K. and Frangi, J.L. (1998) Prestoea montana (R. Graham) Nichols. Sierra Palm. SO-ITF-SM-82, US. Department o Agriculter, Forest Service, Southern Forest Experimental Station, New Orleans, 420-450.

[21] Borhidi, A. (1991) Phytogeography and Vegetation Ecology of Cuba. Academiai Kiado, Budapest.

[22] Reyes, O.J. (2005) Study Synecological Submontane Rainforests on Metamorphic Rocks of the Complex. Foresta Veracruzana, 7, 15-22.

[23] Reyes, O.J. and Acosta Cantillo, F. (2010) Phytocoenoses in the Evergreen Forests of Eastern Cuba. I. Ocoteo-Phoebietum elongatae in the Limestone Hills of the Great Plateau of Guantánamo. Foresta Veracruzana, 12, 9-16.

[24] Reyes, O.J. and Acosta Cantillo, F. (2010) Phytocoenoses in the Evergreen Forests of Eastern Cuba. II. Guareo guidoniae-Zanthoxyletum martinicensis in Sagua Baracoa. Foresta Veracruzana, 12, 1-6.

[25] Reyes, O.J. and Acosta Cantillo, F. (2011) Phytocoenoses in the Evergreen Forests of Eastern Cuba. III. PrunoGuareetum guidoniae in the Sierra Maestra. Foresta Veracruzana, 13, 1-6.

[26] Rivas-Martínez, S. (2005) Notions on Dynamic-Catenal Phytosociology as a Basis of Landscape Science. Plant Biosystems, 139, 135-144. http://dx.doi.org/10.1080/11263500500193790

[27] Van der Maarel, E. (1979) Transformation of Cover-Abundance Values in Phytosociology and Its Effects on Community Similarity. Vegetatio, 39, 97-114. http://dx.doi.org/10.1007/BF00052021

[28] Rivas-Martínez, S. and Loidi, J. (1999) Bioclimatology of the Iberian Peninsula. Itinera Geobotanica, 13, 41-47.

[29] Rivas-Martínez, S. (2004) Biogeographic, Bioclimatic and Vegetation Synopsis of North America. Fitosociología, 41, 19-52.

[30] Galán de Mera, A. (2005) Phytosociological Classification of the Vegetation of the Caribbean and South America. Arnaldoa, 12, 86-111. 
[31] Galán de Mera, A. and Vicente Orellana, J.A. (2006) Approach to Syntaxonomical Scheme Vegetation Caribbean and South America. Anales de Biología, 28, 3-27.

[32] Collevatti, R.J., Lima-Ribeiro, M.S., F. Diniz-Filho, J.A., Oliveira, G., Dobrovolski, R. and Terribile, L.C. (2013) Stability of Brazilian Seasonally Dry Forest under Climate Change: Interferences for Long-Term Conservation. American Journal of Plant Sciences, 4, 792-805. http://dx.doi.org/10.4236/ajps.2013.44098

[33] Lippok, D., Walter, F., Hensen, I., Beck, S.G. and Schleuning, M. (2013) Effects of Disturbance and Altitude on Soil Seed Banks of Tropical Montane Forests. Journal of Tropical Ecology, 29, 523-529. http://dx.doi.org/10.1017/S0266467413000667

[34] Durigon, J., Milena Durán, S. and Gianoli, E. (2013) Global Distribution of Root Climbers Is Positively Associated with Precipitation and Negatively Associated with Seasonality. Journal of Tropical Ecology, 29, 357-360. http://dx.doi.org/10.1017/S0266467413000308

[35] Mejía, M., Pimentel, J. and García, R. (2011) Trees and Shrubs of the Karst Region Haïtises, Dominican Republic. Moscosoa, 17, 90-114.

[36] Cano, E., Cano Ortiz, A. and Veloz, A. (2014) Contribution to the Knowledge of the Edaphoxerophilous Communities of the Samana Peninsula (Dominican Republic). Plant Sociology, 51, in press. 